\title{
À Duesberg, adieu!
}

John Moore

Inventing the AIDS Virus. By Peter H. Duesberg. Regnery: 1996. Pp. 722. \$24.95.

ACCORDING to Bryan Ellison, who cowrote with Peter Duesberg an earlier version of Inventing the AIDS Virus, the US Central Intelligence Agency (CIA) tried to suppress the publication of this book. I can't think why it would want to bother. But conspiracy theories so pervade the book that I shouldn't be in the least surprised if Oliver Stone does the movie.

Duesberg's central thesis is that the human immunodeficiency virus (HIV) is a harmless virus, and that lifestyle (especially recreational drug use) is the principal reason why people die of AIDS. The use of AZT as an AIDS therapy is blamed for exacerbating the problem. In the first section of his book, Duesberg tells the story of an obscure syndrome (SMON) present in Japan from the 1950 s to the 1970s. Despite persistent theories of a viral cause, SMON was found to be a toxicological problem caused by anti-diarrhoea drugs sometimes used to treat its symptoms. Duesberg draws an analogy between these events and AIDS, with AZT analagous to the anti-diarrhoea drugs. An interesting tale, but documenting this and a few other old medical mistakes scarcely proves that AZT

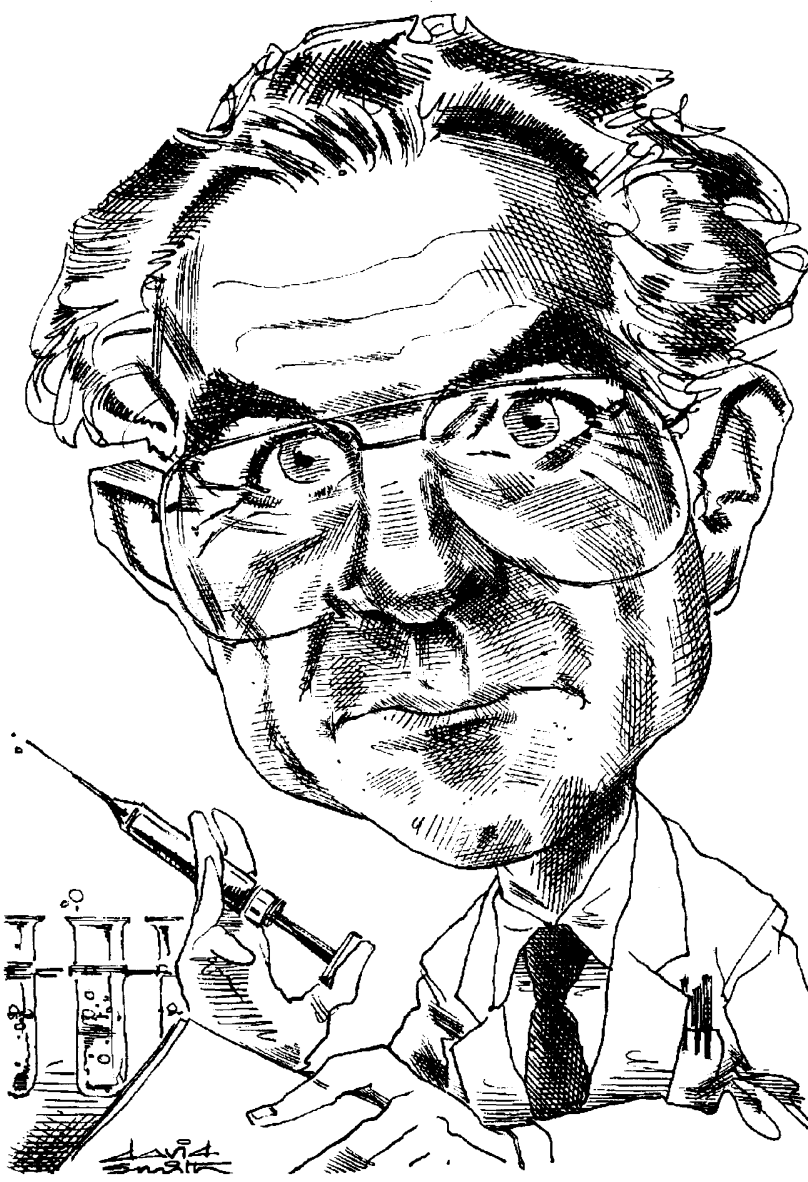

Control (CDC). The Epidemic Intelligence Service (EIS) of the CDC is described as "the medical CIA" and ex-members of the EIS are said to "have obtained prominent positions in the media". One even edits a scientific journal. How sinister! Whatever next? Essentially, Duesberg's case is that the fundamental purpose of the CDC is to invent medical emergencies for the National Institutes of Health to resolve - anything is justified so long as the tax dollars just keep on rollin'. Implicit, and often explicit, is that tens of thousands of health-care professionals and research scientists are either too stupid to realize that HIV is not the cause of AIDS, or too venal to do anything about it for fear of losing income from the gov- ernment or drug companies.

Duesberg mounts an assault on the virology "establishment", with special emphasis on the tumour virologists of the 1960s and 1970s. Researchers' mistakes, real and opined, are gleefully documented - a veritable virological Who's Who is castigated. And the trend continues when the HIV section is finally reached. There, all the 'big name' retrovirologists of the 1980s are targeted, and the early scandals of AIDS research are picked over yet again. So many scientists and so many of their "mistakes" are listed that I was eventually reminded of the old joke about the brigade of guards on parade, with one little guardsman horribly out of step. When the drill sergeant bawls at him, an old lady attacks him with an umbrella saying: "Leave him alone, my boy Peter is in step, it's all them other so-and-so's what are the problem!". All this ancient history is very entertaining, but it hardly seems central to the purpose of the book. Or is it?

Although some vengeance might be expected from a virologist whose eminent career was ended by the AIDS epidemic, one might have wished for a better understanding of modern virology from Duesberg. One of his main complaints about HIV and other 'slow' viruses is that they "violate the laws of virology". But what are these laws? Was it carved in stone that the Lord God spake unto the retroviridiae and commanded: "Thou shalt not kill"? The great beauty of biology indeed, of science in general is that as knowledge advances, so paradigms shift; if HIV acts differently from the viruses Duesberg grew up with, what of it? And herein, I suspect, lies the basic problem: Duesberg clearly has an outstanding knowledge of the relatively simple avian leukaemia viruses with which he made his professional reputation. But he draws his views on how HIV 'should' behave from this early research experience; he has never published any papers based on his own work with HIV at the laboratory bench. Reading the AIDS literature can take one only so far: experimenting gives active researchers a whole new dimension to their knowledge.

I can list here only a few of the more egregious examples of Duesberg's misunderstanding of HIV virology. He states that "retroviruses do not kill cells". This assertion is not even correct for all avian leukaemia viruses, and anyone who has
This contains all the facts, and I strongly recommend people to read it. Of course, 
cultured HIV can attest to its prominent cytopathic effects. HIV is not a leukaemia (onco)virus; it is a lentivirus, and behaves distinctly differently from the oncoviruses both in vivo and in vitro. To extrapolate from avian leukaemia virus to HIV is like asserting that because one can stroke a pussy-cat with impunity, it is perfectly safe to put one's head in a lion's mouth. Duesberg sees a fatal paradox in the fact that HIV can be grown in permanently infected, immortal T-cell lines in vitro, yet is supposed to cause AIDS by killing $\mathrm{T}$ cells in vivo. There is no such paradox. When a chronically infected cell culture is started, clones of cells relatively resistant to the cytopathic effects of HIV are gradually selected for and eventually take over the culture. There can also be some adaptation of the cells (and virus) to the culture conditions. The principal phenotypic change in the cells is a partial reduction in the surface expression of the HIV receptor, which reduces the extent of cell-killing in the culture. But the HIV produced in these cultures is still highly cytopathic when plated back onto unadapted primary $\mathrm{T}$ cells. And sadly, HIV produced from permanent cell lines is pathogenic in vivo - it is today causing disease in at least one

\section{Also on AIDS \\ AIDS: Virus- or Drug-Induced? edited by Peter H. Duesberg. Kluwer, DFI75, $\$ 49.50, \$ 33.75$. Two dozen scientists, scholars and journalists question what they see as the "status quo" of AIDS research. Reprints selected \\ correspondence between Nature and Duesberg.}

AIDS in the UK: The Making of Policy, 1981-1994 by Virginia Berridge. Oxford University Press, £45 (hbk), £12.99 (pbk). A scholarly and immensely detailed account of the reaction of the political and medical establishments, and of the public, to the advent of AIDS in the United Kingdom.

\section{The Gravest Show on Earth: America in} the Age of AIDS by Elinor Burkett. Houghton Mifflin, \$22.95. A journalist's account "of science run amok, of backroom deals between activists and government bureaucrats, of biotechnology companies manipulating stock prices by manipulating research results. It is a tragedy of bungled research, scientific and activist vanity, the dangers of political correctness and, finally, the price more than a million Americans are paying for a nation's folly."

WHO Model Prescribing Information: Drugs Used in Sexually Transmitted Diseases and HIV Infection. World Health Organization, SFr25 (developing countries, SFr17.50) (pbk). A practical guide for clinicians to the selection and prescribing of essential drugs, especially in developing countries. accidentally infected laboratory worker.

Duesberg writes: "Only rare luck... can extract HIV from an antibody-positive person". Perhaps I should get the technicians in our laboratory to buy my lottery tickets; they succeed in isolating HIV almost every time they try. Many of Duesberg's problems with the pathogenic effects of HIV seem to lie in his belief that $\mathrm{HIV}$ is dormant in vivo, that HIV-infected people "never have more than one in every 10,000 T-cells actively producing copies of the virus". This old canard, derived from research in the mid-1980s, has long since been proved incorrect. In the early days of HIV research, analytical techniques were obviously more primitive than they are now, so why still rely on them? The true figure for the frequency of infected cells is more like 1 in 100 , although there is a wide range, depending on the state of disease progression. The documented loss of more than a hundred million $T$ cells a day as a result of the generation of more than a billion virus particles a day attests to the virulence of HIV.

Duesberg points out that the opportunistic infections suffered by AIDS patients are unrelated to each other, and finds this hard to reconcile with any common cause, let alone HIV. The common cause is that opportunistic infections generally happen because of a dysfunctional immune system, and the cause of this dysfunction is usually HIV infection. Of course, there can be other causes genetic or environmental - but rarely is the dysfunction as devastating as that found in the later stages of HIV infection, and never is it as common.

Duesberg believes that HIV is essentially not a sexually transmitted virus; indeed, the very cover of his book states that "AIDS is not sexually transmitted". Instead, he argues that "HIV has been passed along from mother to child for many centuries". The first statement ignores the entire body of data on the epidemiology of HIV spread in the United States and Europe, whereas the second ignores the death rate among children infected by HIV from their mothers; only a tragically small proportion of these children survive long enough to have the chance of having children of their own. How could transmission from mother to child permit sustained HIV spread under these conditions?

Much space is devoted to the thesis that AZT causes AIDS. AZT is decried as a toxic chemical, which of course it is to an extent. So are most chemotherapeutic agents used against cancer. So are paracetamol, rock salt and water if consumed in the wrong quantities. Like all drugs, AZT has a therapeutic window - a dosage that has maximum effect on its target (HIV) and minimal effect on the working of the human body. This fundamental pharmacological principle is criti- cal for understanding AZT's (admittedly limited) effect on HIV replication in vivo. Adding human interest to an otherwise dry section are the numerous quotations from people who believe that AZT has harmed them or their infants. But what of Elizabeth Glaser, who later founded the Pediatric AIDS Foundation? She was infected by HIV through a blood transfusion, and then passed the virus to her children. None of the family used recreational drugs. Sadly, Elizabeth and her daughter Ariel eventually died of AIDS. But at a critical stage of Ariel's disease, Elizabeth managed to obtain AZT for her unconscious child. I quote below from In the Absence of Angels, Elizabeth's book: "Three weeks to the day after we started intravenous AZT I walked into Ariel's room in the morning and she looked up and said 'Good morning, Mom. I love you'.... She hadn't talked in three months!.... It was the miracle we had been waiting for". No AIDS researcher pretends that AZT is the answer to AIDS. But neither is it the cause of it. Most people who die of AIDS have never taken AZT or any other Western drugs. Neither have the monkeys that die from AIDS induced by molecular clones of SIV, a lethal close cousin of HIV.

Duesberg wraps together his twisted facts and illogical lines of argument to create a tangled web to trap the unwary, desperate or gullible. But however much he attempts to gild his writings with philosophies of scientific truth, the reality is that his premises are based not on facts but on faith: faith that he is right, and everyone else is wrong. This was his position long before AIDS appeared, as tumour virologists know well.

Duesberg ends by detailing his ostracism by the virology community, his inability to get research funding, the personal snubs he has suffered. The advent of HIV has clearly been a personal tragedy for a once highly respected retrovirologist, but one's sympathy must of course be tempered by thoughts of those for whom AIDS has been a rather greater personal tragedy. Three years ago, I likened Duesberg to the Black Knight from "Monty Python and the Holy Grail". This character had his limbs hacked off one by one, but the game little torso tried to bite the knee-caps from his assailant. The events of the past few years have extracted the Black Knight's teeth, leaving him with the sole recourse of spitting at those whose views of virology have differed from his over the past two decades. But where the spittle lands is on the graves of those millions of people killed by HIV, and on those it has yet to slaughter. How sad, and how ultimately pathetic.

John Moore is at the Aaron Diamond AIDS Research Center, 445 1st Avenue, New York, New York 10016, USA. 